\title{
"Parenting with Rumah Keluarga Risman" Facebook group as information society and determinant of technology function
}

\author{
Tri Juniati Andayani \& Zainal Abidin Achmad \\ Direktorat Jenderal Pajak Kementerian Keuangan, Jakarta \\ Address: Jalan Gatot Subroto Kav. 40-42, Jakarta 12190 \\ Communication Science, Faculty of Social and Political Sciences \\ Universitas Pembangunan Nasional Veteran Jawa Timur \\ Address: Jalan Raya Rungkut Madya Gunung Anyar, Surabaya 60294 \\ E-mail: z.abidinachmad@upnjatim.ac.id
}

\begin{abstract}
The information society uses the means of information technology with high intensity in everyday life. Facebook groups provide function as an information society. One of the unique groups is "Parenting with Rumah Keluarga Risman" as the research subject. This qualitative research uses the virtual ethnography method to observe both real field and virtual field. As observer-participants, researchers conducted virtual inquiries and indepth interviews with informants of the research subject. The members of the "Parenting with Rumah Keluarga Risman" Facebook group represent their selves whether as a real community and a virtual community. This community often holds meetings in a public space of a city. The intensity of this virtual community is more intensive when having shared problems. The group provides many useful information about parenting, such as avoiding pornographic content for children, book discussions, and social agenda. The communication intimacy among members exceeds the real community. The contents of the communication discussing knowledge parenting in Islamic perspective. The results showed this Facebook group is a concrete form of the concept of determination of technology and information society.
\end{abstract}

Keywords: technology determination, information society, new media, Facebook group, virtual ethnography

\section{Introduction}

Human life depends on technology that it has a substantial contribution to society. Information and communication technology surrounds most aspects of human social life (Meisyaroh 2013). As the determinant of life, technology believes that technology is the driving force of history and affects not only communication but also thought and culture. When people use communication technology with very high intensity, society goes to an information society. One of the information society's characteristics is the duration and frequency of mass media and social media (Achmad 2019; Achmad \& Ida 2019).

Social media is an online medium where users can share, participate, and create content. Forms of participation can be writing, chat, comments, virtual forums, expanding social networks, and online journalism (Alamiyah \& Achmad 2015). The development of modern technology provides benefits with creating various kinds of social media (Gramlich 2019). One popular social media is Facebook because it has a vast network, and almost all age segments can use it (Pai et al. 2017). According to Technobusiness.id, Facebook is the most familiar social media for people. In addition to ease of use, Facebook provides several facilities supporting the good for people's lives, including social care, political activism, kinship, and e-commerce (Achmad et al. 2020; Arviani, Prasetyo, \& Walgunadi 2020; Candrasari 2020; Ellison, Steinfield, \& Lampe 2007; Tutiasri, Kusuma, \& Sumardjijati 2019).

Based on Kominfo.go.id data, in 2013, 95\% of the 63 million Indonesians used the internet to access social networks, and most people access Facebook. Technobusiness.id data shows that as many as 2.3 billion people in the world use Facebook and shows an increase from year to year. Indonesia is among 
the ten countries, with the largest Facebook users in the world in 2019. Indonesia is in the fourth position with the same number of users as Brazil, with 130 million accounts (https://technobusiness.id/).

One of the facilities from Facebook that gets the most support from users is the Facebook group. The purpose of creating a Facebook group is to provide a space for community groups or virtual communities to communicate about shared interests (https://brandee.edu.vn). If someone decides to join a Facebook group, he will find out more information about the profile, activities, documentation, and advantages/disadvantages of joining. Some of the benefits of joining the Facebook group include increasing knowledge, increasing friendship, solving problems, promoting activities, expanding networks, and sharing information. Meanwhile, the disadvantage of joining a Facebook group is the potential for experiencing much bullying and receiving rampant hoax news.

One of the best advantages of Facebook groups is that they can discuss space in the virtual world. Not a few educational institutions use Facebook groups as a learning medium. Another advantage of joining a group is that friendship is expanding because they can get to know each other without restrictions. The latest development is using the Facebook group as a medium for promoting and selling goods and services. Facebook is one of the best radio media partners for advertising and promotion (Achmad, Juwito, \& Saud 2020).

"Parenting with Rumah Keluarga Risman" is a unique Facebook group (https://www.facebook.com/groups/parentingrkr/) because it provides useful information about parenting and has more than 272.300 members. Elly Risman, a popular book writer in Indonesia about parenting, created this group. This group has an Islamic perspective in parenting experiences. Some activities are discussing books, parenting experience for children whose mothers are public workers, avoiding pornographic content for children, and many more. Researchers want to elaborate more about the benefits of this group in making changes to people's lives. Moreover, find evidences of support for the concept of determination in technology and information society.

\section{Methods}

This qualitative research uses the virtual ethnographic method. Christine Hine introduced this recent research method, a combination of classical ethnography and internet ethnography (Achmad \& Ida 2018; Hine 2000). This method requires the researcher to conduct a virtual and real-life search of the research subject and informants. Researchers have lived in two worlds for a certain period, taking into account the need for interaction with the subject, data sufficiency, and the need for analysis (Achmad, Ida, \& Mustain 2020; Angelone 2018; Hair \& Clark 2003; Hine 2008). Participant researchers became members of the Facebook group "Parenting with Rumah Keluarga Risman" and involved intermittently according to discuss themes and agenda on the account https://www.facebook.com/groups/parentingrkr/events.

The researcher openly mentions the reasons for joining the group; this is the best way for virtual ethnographic research so that the researcher can enter the group. The number of informants in this study was eight people, representing several professions and social status, including: traders, housewives, civil servants, students, cleaning services, and freelancers. Informants have an age range between 20 - 50 years with the senior high school to undergraduate education levels. Researchers collected data directly through interaction with subjects through virtual searches and conducted online interviews via Facebook messenger. 


\section{Results and Discussion}

In 1962, Marshall McLuhan first introduced technological determination in his article The Guttenberg Galaxy: The Making of Typographic Man. Changes in how to communicate will shape people's lives is the basic idea of this theory. The presence of technology will affect humans in terms of how to think and behave. There are changes in thought patterns and behavior, leading individuals to move from one technology to another. All of McLuhan's thoughts are based on the belief that the media shapes the human environment, society, and disrupts life (Tremblay 2012).

According to Marshall McLuhan, communication technology is a medium that is the message itself. The medium creates physical pleasures and relaxation. All media are the existence of some human psychic or physical (McLuhan in Tremblay 2012). An example to illustrate the point of Marshall McLuhan's statement is that a magic show that appears on television is more fun. However, when the radio broadcasts the show, magic becomes unattractive. The message from any media or technology is a change in social patterns, so according to McLuhan, the media shapes and controls human relationships and actions. Therefore, the medium becomes essential.

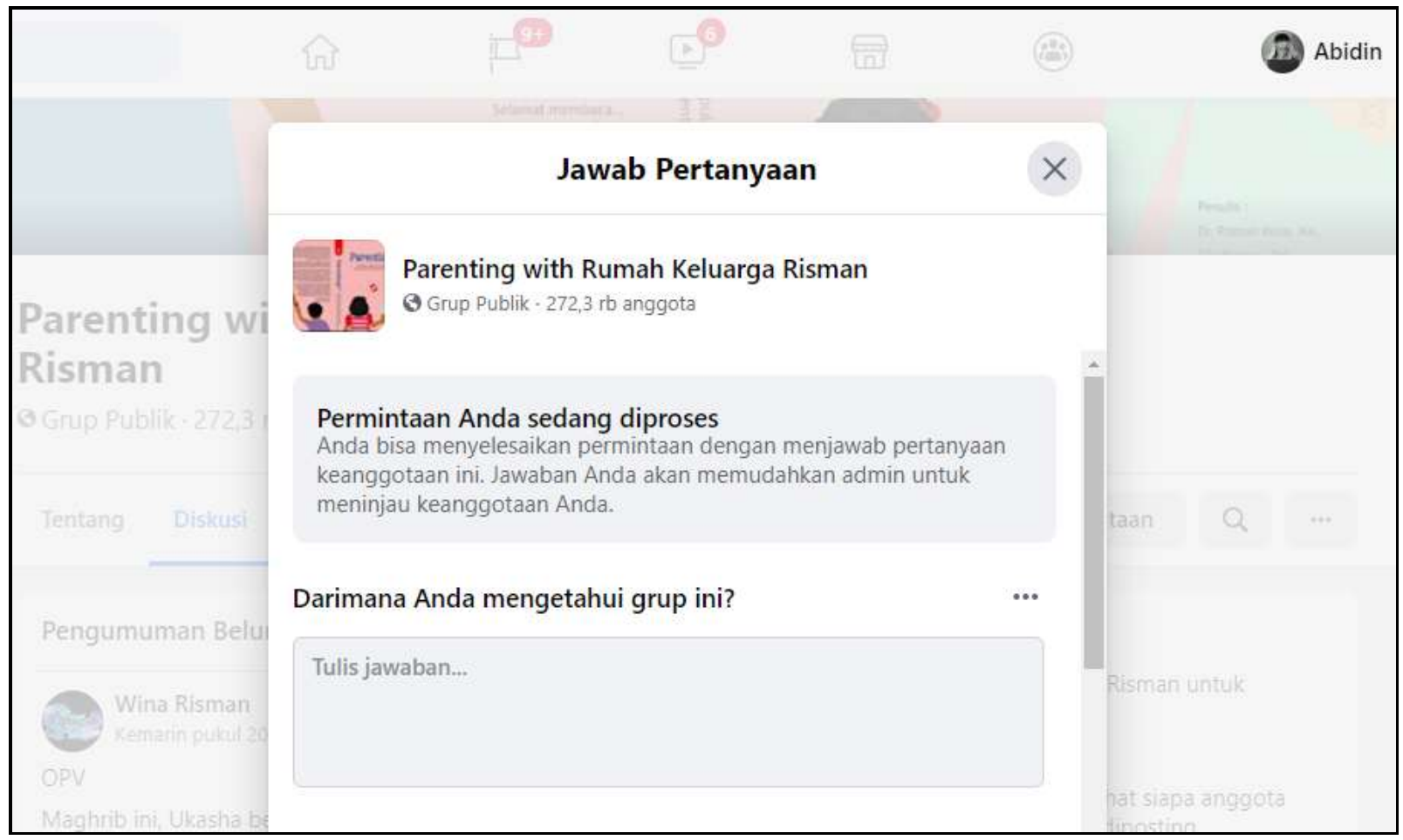

Figure 1

Researchers must introduce as a participant observer to join this group

The media undergoes developments and changes that can restructure social interdependence patterns in every aspect of social life. Change can occur dramatically in all things, such as ourselves, the environment, education, work, government, relationships. These changes force to look back and evaluate the actions and thoughts that have occurred. Media will continue to evolve and form the basis of human history. McLuhan in Tremblay (2012) divides media into three categories, namely oral culture, printing machine civilization, and electric civilization. One of the essential theories from McLuhan is technological determination. In his work, he explains that the media shapes society and individuals. Compared to technological over-determination, social, economic, cultural, and political factors have only a small impact on people's lives (Tremblay 2012). How powerful is the influence of 
technological determination based on this research, because technological developments from time to time, sooner or later, will bring changes in all sectors of life.

The technology consists of production objects, such as tools and containers that aim to enhance human capabilities and enable people to perform tasks they cannot do (Grubler 1998). Technologies are like axes, arrows, hammers, pots, buildings, machines, labor, raw materials, software, and others. Technology that continues to move and change according to the times makes technology includes something that humans make and everything. McLuhan in Alvarez (1999) argues that technology changes society independently. Technology has both positive and negative effects. The technology has a bivalent nature, which means that it can function for both good and evil (Alvarez 1999). Technology develops according to changing times so that the types of evil or goodwill develop by technological developments.

According to Mascuz in Wahab et al. (2012) defines technology as an information need that aims to achieve specific production results, and as a tool to combine and process selected inputs, including production processes, organizational structures, management techniques, marketing methods, and others. According to Tepstra and David in Wahab et al. (2012), technology is a cultural system that deals with humans and their environment. According to experts, the definition of technology also adapts to environmental conditions. Defining technology is not as easy as turning our hands because the environment and people's lives are very influential in defining technology. Some of the definitions above have one thing in common; namely, technology is a tool. The type of equipment adapts to the technical conditions because the technology is continually changing according to each region and individual's conditions.

McLuhan's three main thoughts in Febriana (2018) are about determination, discoveries in communication technology affect cultural change because changes in communication shape the continuity of human life. Initially, humans made tools, and now these tools shape humans. Based on these three main frameworks of thought, McLuhan stated that human civilization's core is media (Febriana 2018).

Technology derivation is a term that describes a diversity of realities that view the relationship between companies and technology and other aspects of human activities (Bimber 1990). Bimber's statement is based on the thoughts of Karl Marx, who was a figure who promoted this theory. Technology explains how humans deal with their environment. The use of technology can help people see the use of products, work done, social relations, communication, and people's thinking. There are three concepts of technological determination according to the paradigm of Marx in Heilbroner (1967), namely technological progress, technological progress is responsible for the social direction, technological changes must be in line with changing social conditions. According to Alvarez (1999), technology determination is the technology that acts as an act of independent force in people's lives. Winner in Alvarez (1999) also reveals that technology is a force beyond human control, and technological determinism is the leading cause of social change. Technology affects humans, meaning that technology is the master of society.

Trembley's (2012) research results reveal that technology influences social, economic, and political life. If the individual does not want to miss technological changes, that individual must keep abreast of changes. Technology moves forward, but many other things are left behind (Volti in Alvarez 1999). Society will find it difficult to predict technological changes that will develop according to the times. Volti in Alvarez (1999) also reveals that all countries must follow technology development because it requires the improvement of a series of steps and stages of all countries. Technology forces similar constraints to organizations in society. In response to technology, values and behavior patterns reflect a rational approach to life. Technological developments and the need for technology today drive the needs of society. 
Technology is a tool that humans use and develop according to human needs and logic. At the same time, determinism is an understanding that considers all actions or events to be the result of previous events and against their will. Hence, the determination of technology is the influence of technological development on all human events and actions. The development of technology makes people do things outside their minds. Technological changes from time to time affect these actions. The media must continue to make changes following technological developments (Febriana 2018). This means to meet society's desires because technology affects the consumption patterns of media users.

The technological determination theory broadly explains the technology, especially the media, which significantly affects individuals' feelings, thoughts, and actions. Meisyaroh (2013) shows that technology determination has a relationship with social media and can affect people's lives. Cahyono (2016) explains that social media affects the social life of the community. This theory continues to develop, along with technological developments. The development of technology gave birth to the internet, thus influencing the development of the mass media. These changes have resulted in the emergence of new media, such as social media. Cahyono (2016) found that social media has positive and negative influences on its users. This theory also continues to develop following these changes.

Webster (2006) defines an information society as a society that carries out significant activities based on five things, namely technology, economy, work, spatial, and culture. People use the same technology to carry out various personal, social, business, or fill their spare time. The characteristics of the information society, according to Webster (2006) are: (1) Technology, the use of information technology for various activities, such as social activities, business, and education. (2) Economy, the information society depends on technological developments, primarily to support its economic activities. (3) Jobs that use technology. (4) Spatial, the reach is getting more expansive because it is connected through networks and has crossed time and space boundaries. (5) Culture in everyday life began to change due to the availability of information and various media channels, including social media. Currently, social media is a new media due to technological developments. One of the new media is Facebook.

Since the 1990s, new media theories have emerged. Digital information spread through digital media is a form of the rapid development of communication and information technology. The use of new media can be in various ways, such as focusing on the message and social context of the use of the media (Friedman \& Friedman 2008).

New media includes a wide variety of communication technologies. Communication technologies include the web, blogs, wikis, online social networks, virtual worlds, and other social media (Friedman $\&$ Friedman 2008). The use of the word new in new media implies a time factor. However, technology continues to evolve, so that the new word will shift its use. Network media will look more precise than the new word (Friedman \& Friedman 2008). New media use focuses on messages, technology, and social context.

According to Friedman and Friedman (2008), there are three aspects to new media: collaboration, digitization, and telecommunications. At present, many new media have emerged as a form of merging old media, giving birth to something new. An example is a smartphone (smartphone), which is one form, can enjoy the diversity of media in it. Smartphones result from the collaboration of various old media with digitization. Furthermore, they connected to the internet, and this smartphone can have a function for communication. Manovich in Friedman and Friedman (2008) defines new media as cultural objects that use digital computer technology as a means of distribution and exhibition.

People often use social media, which is one of the new media. Social media is very diverse. Examples of social media currently have many users are Facebook, Pinterest, Instagram, LinkedIn, and Twitter (Duggan 2015). Based on Muklason and Aljawiy's (2012) research, in 1999, Epinions.com developed a social network based on trust, and Bishop Jonathan is friendship-based. In 2001, Ryze.com emerged as a social network for business. Then Friendster, which has been broadcasting in the community for four 
years, and Indonesia as the number three user on this social media. Technological developments make the competition even tighter. Facebook, founded in 2004, began to expand and shift Friendster's position as social media among students and college students. Muklason and Aljawiy (2011) revealed that Facebook has more and more mature applications.

People use social media a lot, one of which is Facebook. Halloran and Thies (2012) reveal that Facebook has more facilities, great social media, free, simple, quite intuitive, practical, all about connectivity, a great place to share, and is a way for someone to communicate with others. One can use a Facebook page as a place to share all kinds of information, for example, text, photos, videos, and web link. Other users who are already connected referred to as friends. The public can respond through the comments column or the existing facilities on Facebook. On Facebook, there is no limit to the type of response, whether positive or negative. People can do more with Facebook (Halloran \& Thies 2012). Facebook has many facilities, including Facebook chat, timeline, upload videos, upload pictures, Facebook groups, and others.

Facebook users use their accounts to form Facebook groups. Users who create groups on Facebook are administrators. Based on Facebook, there are three characteristics of Facebook groups: open, closed, or secret. Administrators can add or remove users who join the group. Users can also control the activities in the group. If the nature of the group is open, then other users can freely join the group. The advantage of Facebook groups is that they can connect and communicate with a particular group of people, become a discussion forum with specific topics, add event features and set calendars to be well scheduled, and manage and control member access (https://brandee.edu.vn). Users who have an interest in certain things being recommended creating groups. Groups are on the left side of the Facebook page. One can search by entering the group name.

Facebook groups can teach, form the same social group, and are free (Wang et al. 2011). Facebook groups have many advantages but also have limitations. Limitations in Facebook groups include some unsupported formats, such as uploading documents, publishing in threads, and the notion that Facebook has a less secure environment. In Halloran and Thies's (2012) book, they make Facebook groups a medium for selling. Users who join Facebook groups do not have to be friends, so the possibilities for information and social networks are more extensive. Whatever the user has shared in the group, other users who are part of the group will also enjoy whatever it is. Kurnianto (2017) shows that users of the Facebook group "Info Cegatan Jogja" influence the opinions those appear in the group. In Facebook groups, fellow users can carry out various activities such as commenting on each other, discussing each other, and giving each other feedback with the available features. Pai et al. (2017) use a Facebook group to conduct learning at school. Research results from Puspoadi (2017) show that social capital formed through social media through unique patterns.

Facebook is a widely used information media to get the latest information, both local, national, and international information. Facebook has many facilities, one of which is the Facebook group. Groups mostly recommend for users who have a specific interest. Whatever group users, other users who are members of the group, share can enjoy that.

The data obtained from observations is that people access Facebook groups in their spare time. There are various reasons behind someone accessing a group, such as looking for information related to things the user needs, filling spare time, looking for entertainment, communicating with friends or distant relatives, and selling. They access Facebook groups any time at any time; there are no restrictions. People can access Facebook via mobile phones, making it easier for users to access these social media. There are no time and space limitations. The facilities offered and the various kinds of information presented to make people feel comfortable and receive benefits. 


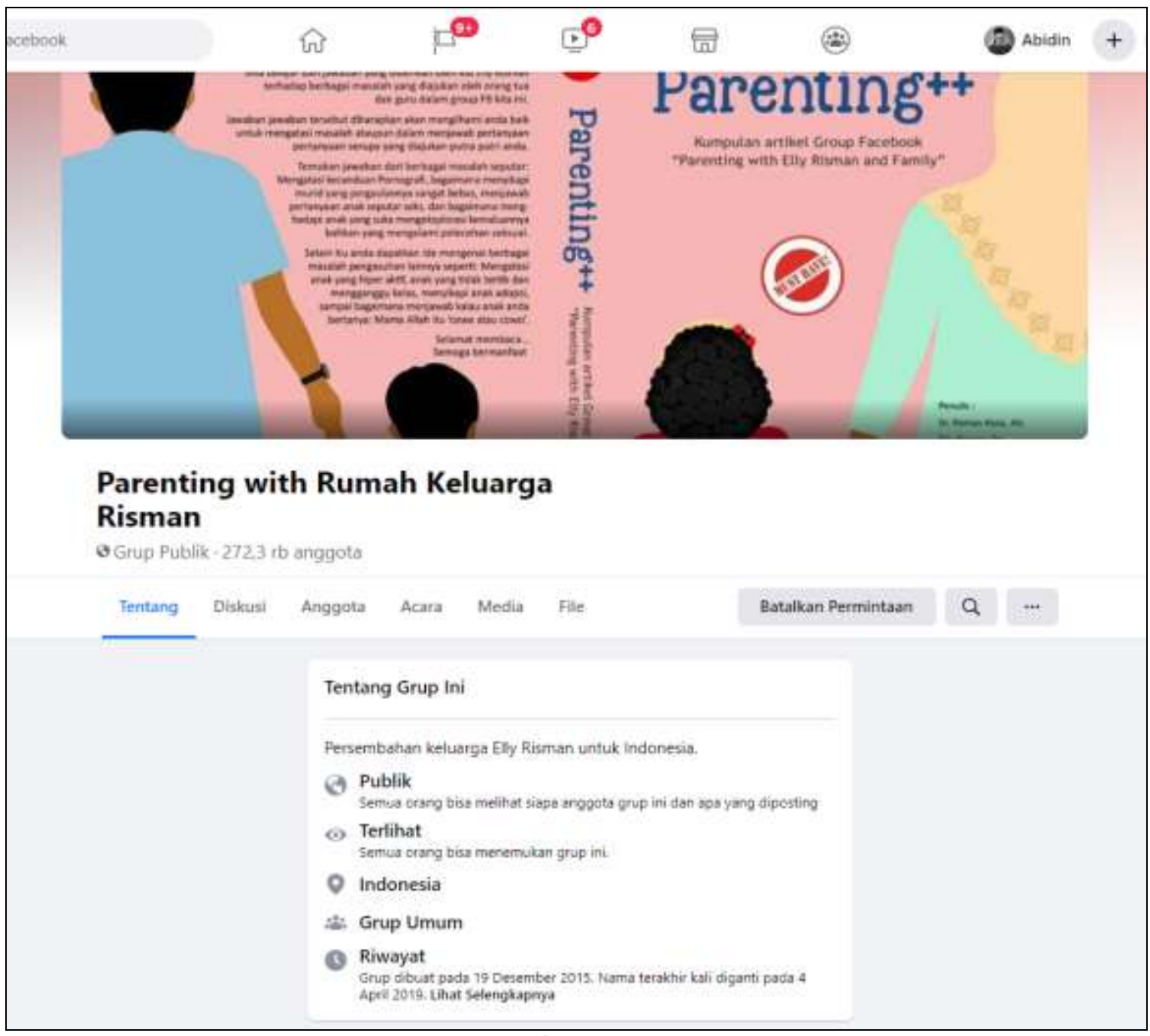

Figure 2

Facebook group account of "Parenting with Rumah Keluarga Risman"

The impact of using Facebook groups also users feel in everyday life. For example, one of the respondents observed that when they were confused, looking for a food menu, they would open a Culinary Group where they were. Then a homemaker learns about family management through Facebook groups such as Parenting with Rumah Keluarga Risman (https://www.facebook.com/groups/parentingrkr/). Some people access Facebook groups to make sales; one example is buying and selling houses and land (https://www.facebook.com/groups/1429157197388421/learning_content/). So that they will open Facebook groups more often because communication takes place within the group.

The results of the interviews showed that the eight informants used Facebook and joined Facebook groups. Activities carried out on social media include uploading the latest status, promoting merchandise, communicating with friends or distant relatives, posting shit, looking for entertainment, looking for the latest news, doing group assignments, political discussions, seeking information, and online shopping.

Not all informants agree that Facebook groups are beneficial for life. One informant considered Facebook groups to be of less use. Facebook groups only used for social media purposes. Besides, some informants revealed that the Facebook group was less beneficial because there were already many 
social media that provided facilities that were more accessible and more up-to-date. Six informants agreed that the Facebook group provided benefits for their lives. Besides being able to increase income through the goods they offer, Facebook groups also provide the latest information related to many things, such as politics, economy, social, and others. Another reason is that Facebook groups have become entertainment for some people by posting funny things or posting shit. From the upload, there is entertainment for the up loader.

Eight informants felt the impact of the presence of the Facebook group. Based on the interview results, Facebook groups have a negative and positive impact. The positive impact of using Facebook groups are users can express what is on the mind, make life easier, help complete group assignments, quickly get the latest information, increase sales, make it easier to offer merchandise, and make communication easier. The negative impact is that advertisements always appear that follow continuously.

This study shows that "Parenting with Rumah Keluarga Risman" Facebook group is part of the determination of technology and information society. It provides continuous interaction with Facebook groups. Eight informants used Facebook and joined the Facebook group. Facebook is a social media that is still relatively new at this time-presenting a variety of attractive features and benefits for users. One of them is the Facebook group feature. People use Facebook groups in their daily lives. They use this technology for various personal, social, business activities or fill their spare time.

Currently, many people seek information first through social media before making decisions. They complete the information and add knowledge, then make decisions. As revealed by Supriyono, one of the respondents who work as Pegawai Negeri Sipil (PNS) or a Civil Servant that he accesses Facebook groups to find information.

The convenience offered makes it easy for people to access anywhere. One respondent named Ika, who works as a cleaning service, said that accessing Facebook groups in a day is countless. That means that the Facebook group has become a part of him. He also revealed that Facebook groups were beneficial and had a significant impact on his life. The things he gets from Facebook groups include selling online, shopping online, and searching for various information. On the sidelines of his job as a cleaning service, Ika accesses the Facebook group through his mobile phone. That shows that the community has become part of the information society where its activities have characteristics owned by the information society. The characteristics referred to are the use of information technology for various activities, society depends on technological developments, work is dominated by technology, its broad reach is not limited by time and space, and the culture begins to change. At one time, people can carry out various activities that can add value to their lives.

Besides being included in the information society, Facebook group users are also a tangible manifestation of technological determination. That can be seen from the research results that show that Facebook groups provide more benefits and impact society, both negative and positive. Following the concept of technological determination, which considers technology to be the driving force of history and can influence communication, thinking, and community culture. Three thoughts of Mcluhan that influenced this, namely the global village, the medium is the message and hot and cold media.

Facebook group is a form of the global village that is meant in Mcluhan's thinking. Communication technology has reduced the earth to a village through instant and available information anywhere and anytime. The community no longer needs to gather in a large field or meet face to face to carry out their daily activities. It is currently enough to sit at home, open a Facebook group, and interact with other people. For example, the activity carried out by Maybe, one of the Zimbabwean students currently studying in Surabaya, said that:

"Ya. Actually make my life more easy. Seperti saya mahasiswa di sini, keluarga saya di Afrika, jadi saya gunakan itu untuk berkomunikasi. Dan ada beberapa video itu juga bisa pakai seperti pendidikan. Yah...it's long so like the social media being use in a good way. It's valid to our life, especially education." 
("Yes. Actually, make my life easier. Like I am a student here, my family is in Africa, so I use that to communicate. And some videos can also be used as education. Well ... it's long, so like the social media being used in the right way. It's valid to our life, especially education.")

To communicate with his family in Zimbabwe, he does not need to be face to face. Facebook groups have become a kind of village for him and his family to interact and share the news. Distance is no longer an obstacle to discussing and sharing various kinds of information. He also revealed that Facebook groups make his life more comfortable.

The second thought from Mcluhan about the medium is that the message is also seen from this study's results where Facebook groups as a medium can create physical pleasures and relaxation. Following the thinking about the determination of technology that technology can influence thinking. Moreover, this happens to the community of Facebook group users. As expressed by Dyas, Facebook groups are a place to find entertainment and as part of refreshing their souls through the messages, they convey. Dyas also frequently shits posts and uploads "memes" that can give pleasure to his soul.

Facebook groups are cold media, namely media that require high user involvement. Facebook groups allow people to interact with each other actively. Everyone can be involved, can debate, can discuss, can have two-way communication. As expressed by Emi, through his selling group Facebook account, he offers goods, communicates with potential customers, and expresses gratitude for his trust.

Facebook groups have formed a new habit in society. The presence of technology makes it easier for people to convey various information. As stated in the theory of technological determination, technology influences people's lives. Technological developments make society dependent on this technology. To make people use information technology facilities with high intensity in everyday life. Society depend on technological developments because of the benefits and positive impacts.

\section{Conclusion}

The presence of the "Parenting with Rumah Keluarga Risman" Facebook group as a result of technological developments brings benefits to people's lives. The members can share information and use information. With the Facebook group, their way of communicating has begun to shift, from face to face; they now exchange messages on social media without needing to know each user's background. Educators and academics share knowledge, discuss with each other, and do assignments through social media. Moreover, they feel comfortable with Facebook groups as a place to learn. The members do the buying and selling products and merchandises through Facebook group because the information spread more widely. People in the Facebook group are free to share the vital information about parenting, could discuss privately.

"Parenting with Rumah Keluarga Risman" Facebook group provides benefits and impacts on people's lives. Besides technological changes from time to time, it affects society's life changes. These changes are communication, interaction, sharing, buying and selling, social, cultural, and even the education system. That is forming an information society, following the characteristics of the information society.

\section{References}

Achmad ZA \& Ida R (2018) Etnografi Virtual Sebagai Teknik Pengumpulan Data dan Metode Penelitian. The Journal of Society \& Media 2 (2): 130-145. https://doi.org/10.26740/jsm.v2n2.p130-145.

Achmad ZA \& Ida R (2019) The shifting role of the listeners in the mediamorphosis process of culture radio: A case study of Jodhipati 106.1 FM. Masyarakat, Kebudayaan Dan Politik 32 (3): 240-250. https://doi.org/10.20473/mkp.v32i32019.240-250. 
Achmad ZA (2019) Integrasi Program Dakwah dan Budaya: Studi Etnografi Virtual Mediamorfosis Radio Nada FM Sumenep Madura. Jurnal Komunikasi Islam 09 (2): 238-263. https://doi.org/10.15642/jki.2019.9.2.239-263.

Achmad ZA, Azhari TZ, Esfandiar WN, Nuryaningrum N, Syifana AFD, \& Cahyaningrum I (2020) Pemanfaatan Media Sosial dalam Pemasaran Produk UMKM di Kelurahan Sidokumpul, Kabupaten Gresik. Jurnal Ilmu Komunikasi 10 (1): 17-31. https://doi.org/10.15642/jik.2020.10.1.17-31.

Achmad ZA, Ida R, \& Mustain M (2020) A Virtual Ethnography Study: The Role of Cultural Radios in Campursari Music Proliferation in East Java. ETNOSIA: Jurnal Etnografi Indonesia 5 (2): 221237.

Achmad ZA, Juwito J, \& Saud M (2020) The Local Creative Ads On Sritanjung Fm To Increase Financial Revenue During Covid-19 Pandemic. Bricolage: Jurnal Magister Ilmu Komunikasi 6 (2): $135-146$.

Alamiyah SS \& Achmad ZA (2015) The role of citizen journalism in creating public sphere in indonesia. In: Proceeding International Conference on Democracy and Accountability (ICoDA), 10 November 2015. Surabaya: Faculty of Social and Political Sciences Universitas Airlangga, 162167.

Alvarez MR (1999) Modern Technology and Technological Determinism: The Empire Strikes Again Bulletin of Science, Technology, and Society 19 (5): 402-410.

Angelone L (2018) Virtual Ethnography: The Post Possibilities of Not Being There. Mid-Western Educational Researcher 31 (3): 275-295.

Arviani H, Prasetyo GS, \& Walgunadi VV (2020) Instagram and Millennial Generation: \#Explorebanyuwangi Analysis. In: Proceedings of the 2nd International Media Conference 2019 (IMC 2019). https://doi.org/10.2991/assehr.k.200325.016.

Bimber B (1990) Karl Marx and the Three Faces of Technological Determinism. Social Studies of Science 20 (2): 333-351.

Cahyono AS (2016) Pengaruh Media Sosial Terhadap Perubahan Sosial Masyarakat Indonesia. Publiciana 9 (1): 140-157.

Candrasari Y (2020) Mediated Interpersonal Communication: A New Way of Social Interaction in the Digital Age. In: Proceedings of the 2nd International Media Conference 2019 (IMC 2019) Advances in Social Science, Education and Humanities Research. https://doi.org/10.2991/assehr.k.200325.041.

Duggan M (2015) Mobile Messaging and Social Media 2015. [Diakses Juni 2019]. https://www.pewinternet.org/2015/08/19/mobile-messaging-and-social-media-2015/.

Dyas (2019) [Personal communication].

Ellison NB, Steinfield C, \& Lampe C (2007) The Benefits of Facebook "Friends:" Social Capital and College Students' Use of Online Social Network Sites. Journal of Computer-Mediated Communication 12 (4): 1143-1168. https://doi.org/10.1111/j.1083-6101.2007.00367.x.

Febriana AID (2018) Determinasi Teknologi Komunikasi dan Tutupnya Media Sosial Path. Jurnal Lontar 6 (2): 10-17.

Friedman LW \& Friedman HH (2008) The New Media Technologies: Overview and Research Framework. SSRN Electronic Journal: 1-28. http://dx.doi.org/10.2139/ssrn.1116771.

Gramlich J (2019) 10 facts about Americans and Facebook (2019) [Diakses Juni 2019]. https://www.pewresearch.org/fact-tank/2019/02/01/facts-about-americans-and-Facebook/

Grubler A (1998) Technology and Global Change. Cambridge: Cambridge University Press.

Hair N \& Clark M (2003) An Enhanced Virtual Ethnography: The Role Of Critical Theory. Exploring the Meaning of 'critique' in Electronically-Mediated Work. 44 (0). http://merlin.mngt.waikato.ac.nz/ejrot/cmsconference/2003/proceedings/exploringthemeaning/Hair. pdf. 
Halloran M \& Thies C (2012) The Social Media Handbook for Financial Advisors: How to Use LinkedIn, Facebook, and Twitter to Build and Grow Your Business. United States of America: Bloomberg Press.

Heilbroner RL (1967) Do Machines Make History?. Technology and Culture 8 (3): 335-345. doi: $10.2307 / 3101719$.

Hine C (2000) Virtual Ethnography. London: Sage Publications Ltd.

Hine C (2008) Virtual Ethnography: Modes, Varieties, Affordances. Dalam: The SAGE Handbook of Online Research Methods. Editor: Fielding N, Lee RM, \& Blank G. https://doi.org/10.4135/9780857020055.n14.

Ika (2019) [Personal communication].

Jual Beli Rumah Tanah Magelang \& Sekitarnya (2019) [Diakses Juni 2019]. https://www.Facebook.com/groups/1429157197388421/learning_content/.

Kominfo: Pengguna Internet di Indonesia 63 Juta Orang (2013) [Diakses Juni 2019]. https://www.kominfo.go.id/content/detail/3415/kominfo-pengguna-internet-diindonesia-63-jutaorang/0/berita_satker.

Kurnianto A (2017) Opini Anggota Grup Facebook Info Cegatan Jogja (ICJ) Terhadap Kinerja Kepolisian di Yogyakarta Tahun 2017. Skripsi, Universitas Muhammadiyah Yogyakarta, Yogyakarta.

Maybe (2019) [Personal communication].

Meisyaroh S (2013) Determinasi Teknologi Masyarakat dalam Media Sosial. Jurnal Komunikasi dan Bisnis 1 (1): 36-46.

Muklason A \& Aljawiy AY (2011) Jejaring Sosial dan Dampak Bagi Penggunanya. Teknologi: Jurnal Ilmiah Sistem Informasi 1 (1). 10.26594/teknologi.v1i1.46.

Pai A, McGinnis Gene, Bryant D, Cole M, Kovacs J, Stovall K, \& Lee M (2017) Using Facebook Groups to Encourage Science Discussion in a Large-Enrollment Biology Class. Journal of Educational Technology Systems 46 (1): 103-136.

Parenting with Keluarga Risman (2019) [Diakses Juni 2019]. https://web.facebook.com/groups/parentingrkr/.

Pengguna Facebook Mencapai 2,32 Miliar: Berapa dari Indonesia? (2019) [Diakses Juni 2019]. https://technobusiness.id/pengguna-Facebook-mencapai-232-miliar-berapa-dari-indonesia/

Puspoadi G (2017) Dari Konektivitas Menuju Kolektivitas dalam Komunitas Grup Facebook Info Cegatan Jogja. Skripsi, Universitas Gajah Mada, Yogyakarta.

Ryze Business Networking (2019) [Diakses Juni 2019]. Ryze.com.

Supriyono (2019) [Personal communication].

The differences between Pages, profiles, groups and events (2019) [Diakses Juni 2019]. https://brandee.edu.vn/glossary/2148431558717386-facebook-en.

Tremblay G (2012) From Marshall McLuhan to Harold Innis, or From the Global Village to the World Empire. Canadian Journal of Communication 37 (4): 561-575.

Tutiasri RP, Kusuma A, \& Sumardjijati S (2019) Perilaku Remaja dalam Penyebaran Hoax di Grup WhatsApp. Jurnal Ilmu Komunikasi 2 (1). https://doi.org/10.33005/jkom.v2i1.36

Wahab SA, Rose RC, \& Osman SIW (2012) Defining the Concepts of Technology and Technology Transfer: A Literatur Analysis. International Business Research 5 (1): 61-71.

Wang Q, Woo HL, Quek CLG, Yang Y, \& Liu M (2011) Using Facebook Group as a Learning Management System: An Exploratory Study. British Journal of Educational Technology 43 (3): 428-438.

Webster F (2006) Theories of the Information Society. New York: Routledge. 